Abstracta Iranicacta Iranica

Revue bibliographique pour le domaine irano-aryen

Volume 28 | 2007

Comptes rendus des publications de 2005

\title{
«Partnership for Central Asia ». Foreign Affairs, vol. 84, n 4, juillet/août 2005, pp. 56-64.
}

\section{Anicée Van Engeland}

\section{(2) OpenEdition}

1 Journals

\section{Édition électronique}

URL : http://journals.openedition.org/abstractairanica/20091

DOI : 10.4000/abstractairanica.20091

ISSN : 1961-960X

Éditeur :

CNRS (UMR 7528 Mondes iraniens et indiens), Éditions de l'IFRI

\section{Édition imprimée}

Date de publication : 15 mai 2007

ISSN : 0240-8910

\section{Référence électronique}

Anicée Van Engeland, « «Partnership for Central Asia ». Foreign Affairs, vol. 84, n 4, juillet/août 2005, pp. 56-64. », Abstracta Iranica [En ligne], Volume 28 | 2007, document 477, mis en ligne le 18 septembre 2007, consulté le 25 septembre 2020. URL : http://journals.openedition.org/abstractairanica/20091 ; DOI : https://doi.org/10.4000/abstractairanica.20091

Ce document a été généré automatiquement le 25 septembre 2020.

Tous droits réservés 


\title{
«Partnership for Central Asia ».
}

\section{Foreign Affairs, vol. 84, $\mathrm{n}^{\circ} 4$, juillet/ août 2005, pp. 56-64.}

\author{
Anicée Van Engeland
}

L'engagement américain en Afghanistan a modifié la position des États-Unis en Asie centrale. Il faut que les États-Unis profitent de leur présence en Afghanistan et de leurs bases dans les autres pays d'Asie centrale pour former un ensemble pour la coopération et le développement. La stabilité en Afghanistan devrait motiver le gouvernement américain à s'installer davantage dans la région. La guerre en Afghanistan a donc ouvert une opportunité d'investissement dans une région du monde intéressante sur le plan économique mais aussi sur les alternatives offertes à l'islam. L'action américaine doit donc désormais se porter sur la création d'un pôle économique qui permettra à ces pays d'Asie Centrale de se développer et aux États-Unis de bénéficier des nombreuses opportunités commerciales.

\section{INDEX}

Thèmes : 13.2. Afghanistan

\section{AUTEURS}

ANICÉE VAN ENGELAND

Paris 